\title{
Perbandingan Algoritma Nearest Neighbour, C4.5 dan LVQ untuk Klasifikasi Kemampuan Mahasiswa
}

\author{
Muhammad Fakhrurrifqi*1 ${ }^{1}$, Retantyo Wardoyo ${ }^{2}$ \\ ${ }^{1}$ Program Studi S2 Ilmu Komputer \\ ${ }^{2}$ Jurusan Ilmu Komputer dan Elektronika, FMIPA UGM, Yogyakarta \\ e-mail: ${ }^{1}$ mfrifqi@gmail.com, ${ }^{2}$ rw@ugm.ac.id
}

\begin{abstract}
Abstrak
Pada pelaksanaan acara perkuliahan atau saat proses balajar mengajar, dosen sering terkendala dengan kemampuan mahasiswa pada suatu matakuliah di satu kelas yang tidak merata. Oleh karena itu dosen terlebih dulu mengetahui kemampuan setiap mahasiswanya dengan salah satu caranya adalah dengan melihat karakteristik setiap mahasiswa dan kemudian dibandingkan dengan mahasiswa-mahasiswa sebelumnya dalam menyelesaian suatu mata kuliah.

Pada penelitian ini, akan dilakukan perbandingan tingkat akurasi antara tiga algoritma, yaitu : Nearest Neighbour, C45 dan LVQ, pada kasus klasifikasi kemampuan mahasiswa untuk keperluan penentuan pembagian kelas mahasiswa baru. Selain itu, juga akan diperbandingkan tingkat kecepatan setiap algoritma dalam mendapatkan kelas kasus lama yang paling mirip dengan kasus baru yang dimasukkan.

Kesimpulan yang didapatkan setelah sistem dibangun dan kemudian membandingkan ketiga algoritma tersebut adalah algoritma nearest neighbour dapat menghasilkan akurasi tertinggi.
\end{abstract}

Kata kunci-nearest neighbour, c45, jaringan syaraf tiruan, lvq, mahasiswa

\begin{abstract}
During the lecture or in teaching-learning process, a lecturer sometimes finds that heterogeneous classroom as the obstacles due to the differences in students' performances. Thus, the lecturer should be aware of this phenomenon and one way to overcome this is to find out the characteristics of each student in order to compare them with the previous students while completing their study.

In this research, the three algorithms are compared, they are namely; Nearest Neighbor, C45, and LVQ, this is done to classify the students' ability and to decide the class for the new students. In addition, the speed level of each algorithm is compared by means of getting the nearest previous case study to the new class.

Finally, the ideas coming up as the conclusion for this research is that after the system is developed and those three algorithms are being compared, the result shows that there is nearest neighbour algorithm can produce the highest accuracy.
\end{abstract}

Keywords—nearest neighbour, c45, artificial neural network, LVQ, students' performances. 


\section{PENDAHULUAN}

$\mathrm{P}$ ada perguruan tinggi, dalam hal ini Universitas Gajah Mada (UGM), disetiap tahunnya dilakukan penerimaan mahasiswa baru. Jumlah mahasiswa yang diterima dapat berjumlah ratusan bahkan ribuan. Latar belakang setiap mahasiswapun sangat beraneka ragam karena berasal dari berbagai daerah yang berbeda-beda dengan kebudaan yang beraneka ragam. Selain itu kemampuan yang dimiliki pada saat diterima menjadi mahasiswa baru UGM pun juga bervariasi.

Sejumlah banyak mahasiswa baru yang diterima akan dibagi menjadi sekian banyak program studi yang dimiliki oleh UGM yang tersebar di berbagai jurusan dan fakultas. Pembagian ini dilakukan berdasar peminatan yang diajukan oleh mahasiswa itu sendiri ketika mendaftarkan diri untuk menjadi mahasiswa UGM. Pada beberapa program studi, mahasiswa baru kemudian akan dibagi lagi menjadi beberapa kelas.

Pada pelaksanaan acara perkuliahan atau saat proses belajar mengajar, dosen sering terkendala dengan kemampuan mahasiswa pada suatu matakuliah di satu kelas yang tidak merata. Hal ini akan menjadi tantangan tersendiri untuk dosen dalam menentukan metode pengajaran yang tepat untuk kelancaran proses belajar mengajar dalam suatu kelas.

Dosen yang mengetahui kemampuan setiap mahasiswanya akan mudah dalam menentukan metode pembelajaran. Akan tetapi, untuk mengetahui kemampuan mahasiswa tentulah tidak mudah, terlebih kemampuan mahasiswa tidaklah sama pada setiap mata kuliah. Oleh karena itu, perlu dilihat karakteristik setiap mahasiswa dan imbasnya pada kemampuan mahasiswa dalam menyelesaian suatu mata kuliah.

Dalam mengukur kemampuan mahasiswa, nantinya dapat diambil data-data yang merepresentasikan karakteristik mahasiswa tersebut, misal : asal mahasiswa, pendidikan orang tua, SMA/SMK asal mahasiswa, dan lain sebagainya. Dari data yang didapatkan dari mahasiswa baru tersebut, nantinya dibandingkan dengan data-data yang diambil dari mahasiswa tahun sebelumnya, kemudian diprediksi nilai akhir mahasiswa baru tersebut.

Terdapat banyak metode atau cara untuk membandingkan data baru dengan data-data lama. Metode yang sering digunakan adalah, case base reasoning (CBR). Metode ini digunakan untuk menentukan kasus lama yang paling mirip dengan kasus baru yang dimasukkan. Kasus lama yang dianggap mirip dapat menjadi solusi, seperti slogan "Similar problems have similar solutions". Dengan demikian, mahasiswa yang dianggap mempunyai karakteristik hampir sama, akan memiliki kemampuan yang hampir sama pula.

CBR telah dikenalkan pada awal 1980an sebagai pendekatan penalaran yang dipercaya didukung oleh ide bahwa orang menggunakan kembali pengalamannya ketika memecahkan suatu masalah. Umumnya, CBR memiliki sejumlah besar kasus-kasus sebelumnya yang tersimpan dalam basis kasus. Ketika ada masalah baru, akan dilihat sebagai kasus baru dan dibandingkan dengan kasus-kasus pada basis kasus. Kemudian, kasus yang mirip dengan kasus baru akan digunakan sebagai saran pada penguna sebagai solusi terhadap masalah baru tersebut. Biasanya, kasus baru yang diselesaikan, akan ditambahkan ke dalam basis kasus. Banyak sistem CBR yang ditelah dipublikasikan untuk memecahkan masalah dalam berbagai bidang, seperti : diagnosis, perencanaan, desain, dan pengolahan citra[1].

Namun kinerja sistem CBR bergantung pada kesesuaian pengorganisasian kasus dan algoritma yang digunakan untuk memanggil kembali dari basis data kasus yang besar. Kebanyakan sistem CBR menggunakan algoritma nearest neighbor untuk pemanggilan kembali pada basis kasus berindeks datar (flat-indexed), yang tidak efisien untuk basis data kasus yang besar.

Sistem CBR juga telah digabungkan dengan beberapa algoritma JST. JST dilibatkan ke dalam siklus CBR untuk mengekstrak pengetahuan. Pada proses pemanggilan kembali, JST akan memanggil kembali data yang paling cocok dengan data input, sesuai pengetahuan yang dimilikinya. JST terawasi (supervised) seperti LVQ (Learning Vector Quantization) melakukan pemanggilan kembali berdasarkan pada pencocokan tetangga terdekat (nearest neighbor matching), karena menyimpan vektor bobot sebagai buku kode atau vektor contoh untuk pola

IJCCS Vol. 7, No. 2, July 2013 : 145 - 154 
input. Pencocokan didasarkan pada proses kompetitif yang menentukan unit keluaran yang paling cocok dengan vektor input, seperti nearest neighbor. Namun pada LVQ, ruang pelacakan sangat berkurang karena generalisasi pengetahuan melalui pelatihan [2] yang menghasilkan vektor bobot. Sehingga tidak perlu membandingkan dengan semua data input, tetapi cukup membandingkan dengan vektor bobot untuk menentukan keluarannya.

Sistem CBR yang lain menggunakan pengindeksan hirarkis seperti pohon keputusan dan C4.5 [3]. Pada CBR, pohon keputusan dikategorikan sebagai teknik pengindeksan kasus dengan pendekatan induktif. Pendekatan induktif digunakan untuk menentukan struktur berbasis kasus. Struktur hirarkis basis kasus yang dihasilkan menurunkan ruang pencarian pada saat proses retrieval [2].

Pada penelitian ini, akan dilakukan perbandingan tingkat akurasi antara tiga algoritma tersebut pada kasus klasifikasi kemampuan mahasiswa untuk keperluan penentuan pembagian kelas mahasiswa baru. Selain itu, juga akan diperbandingkan tingkat kecepatan setiap algoritma dalam mendapatkan kelas kasus lama yang paling mirip dengan kasus baru yang dimasukkan.

\section{METODE PENELITIAN}

\subsection{Case Base Reasoning}

Case Based Reasoning (CBR) merupakan suatu teknik pemecahan masalah yang mengadopsi solusi-solusi masalah-masalah sebelumnya yang mirip dengan masalah baru yang dihadapi untuk mendapatkan solusinya [4]. Kasus-kasus pada masa lalu disimpan dengan menyertakan fitur-fitur yang menggambarkan karakteristik dari kasus tersebut beserta solusinya.

CBR telah banyak digunakan diberbagai bidang. Secara umum aplikasi CBR dikelompokkan menjadi kelompok klasifikasi dan kelompok sintesis [5]. Pada kelompok klasifikasi, setiap kasus dikelompokkan berdasarkan kemiripannya yang dilihat dari fiturfiturnya. Kasus yang baru akan mengadopsi solusi dari kasus-kasus yang berada dalalm kelompok kasus yang sama. Pada kelompok sintesis, solusi didapat dengan cara mengombinasikan solusi-solusi dari kasus-kasus sebelumnya. Kelompok ini biasanya merupakan suatu sistem gabungan antara CBR dengan teknik yang lain.

CBR dapat direpresentasikan sebagai suatu siklus proses yang dibagi menjadi empat sub proses [6], yaitu:

1. Retrieve, mencari kasus-kasus sebelumnya yang paling mirip dengan kasus baru.

2. Reuse, menggunakan kembali kasus-kasus yang paling mirip tersebut untuk mendapatkan solusi pada kasus yang baru.

3. Revise, merubah dan mengadopsi solusi yang ditawarkan jika perlu.

4. Retain, menyimpan solusi dari kasus yang baru.

\subsection{Nearest Neighbour}

Retrieve merupakan suatu proses menemukan kasus-kasus sebelumnya yang disimpan di casee-base yang kemudian digunakan kembali untuk mendapatkan solusi dari kasus yang baru. Retreival merupakan inti dari CBR. Terdapat dua teknik yang sering digunakan dalam retreival pada CBR, yaitu nearest neighbuor dan inductive retreival.

Nearest Neighbour merupakan teknik yang sederhana yang menyediakan sebuah ukuran seberapa mirip kasus baru dengan kasus lama. Pengukuran kemiripan kasus baru dengan kasus lama menggunakan fungsi similarity.

Fungsi similarity (kemiripan) akan menghasilkan nilai yang menentukan apakah ada kemiripan antara kasus yang baru dengan kasus-kasus yang ada dalam case base. Untuk menentukan kemiripan bisa dilakukan dengan beberapa fungsi antara lain dengan fungsi similarity euclidean distance. Namun, Salah satu kelemahan dari fungsi jarak Euclidean ini adalah jika salah satu input atribut memiliki kisaran yang relatif besar, maka atribut ini dapat mengalahkan atribut lainnya. Oleh karena itu, jarak sering dinormalisasi dengan membagi jarak untuk setiap atribut dengan rentang (yaitu nilai maksimum - nilai minimum) atribut itu, 
sehingga nilai untuk masing-masing atribut memiliki rentang baru yang ternormalisasi yaitu 0 hingga 1 [7]. Persamaan (1) merupakan rumus jarak antara dua titik x dan y pada attribut a:

$$
\begin{aligned}
& \mathrm{d}_{\mathrm{a}}(\mathrm{x}, \mathrm{y})=\frac{|x-y|}{\text { range } a} \\
& \text { dimana : } \\
& \text { range } a=\max _{\mathrm{a}}-\min _{\mathrm{a}}
\end{aligned}
$$

\section{3. $L V Q$}

Jaringan Syaraf Tiruan adalah salah satu cabang dari AI (Artificial intelligence). Jaringan syaraf merupakan salah satu representasi buatan dari otak manusia yang selalu mencoba untuk menstimulasikan proses pembelajaran pada otak manusia tersebut. Istilah buatan disini digunakan karena jaringan syaraf ini diimplementasikan dengan menggunakan program komputer yang mampu menyelesaikan sejumlah proses perhitungan selama proses pembelajaran [8].

Learning Vector Quantization (LVQ) adalah suatu metode untuk melakukan pembelajaran pada lapisan kompetitif yang terawasi. Suatu lapisan kompetitif akan secara otomatis belajar untuk mengklasifikasikan vektor-vektor input [8]. Algoritma pembelajaran LVQ sebagai berikut :

1. Tetapkan: Bobot awal variabel input ke-j menuju ke kelas ke-i: Wij, Maksimum Epoh (MaxEpoh), error minimum yang diharapkan, learning rate $(\alpha)$.

2. Masukkan :

$\begin{array}{lll}\text { Data } \text { input } & : \mathrm{Xj} ; & \text { Dengan } \mathrm{j}=1,2, \ldots, \mathrm{n} \\ \text { Target berupa kelas } & : \mathrm{T} i ; & \text { Dengan } \mathrm{i}=1,2, \ldots, \mathrm{m}\end{array}$

3. Tetapkan kondisi awal:

$$
\text { Epoh }=0
$$

4. Kerjakan selama: (epoh<MaxEpoh) dan Eps >minimal error)

i. $\quad$ Epoh $=$ epoh +1 ;

ii. Kerjakan untuk $\mathrm{i}=1$ sampai $\mathrm{n}$

1. Memilih jarak sedemikian hingga $\left\|\mathrm{X}-\mathrm{W}_{\mathrm{j}}\right\|$ minimum

2. (sebut sebagai $\mathrm{C}_{\mathrm{j}}$ )

3. Perbaiki Wj dengan ketentuan:

$$
\begin{array}{ll}
\text { a. } & \text { Jika } \mathrm{C}_{\mathrm{j}}=\mathrm{T} \text { maka : } \\
& \mathrm{W}_{\mathrm{j}}=\mathrm{W}_{\mathrm{j}}+\alpha\left(\mathrm{X}-\mathrm{W}_{\mathrm{j}}\right) \\
\text { b. } & \text { Jika }_{\mathrm{j}}=\mathrm{T} \text { maka: } \\
& \mathrm{W}_{\mathrm{j}}=\mathrm{W}_{\mathrm{j}}-\alpha\left(\mathrm{X}-\mathrm{W}_{\mathrm{j}}\right)
\end{array}
$$

iii. Kurangi nilai $\alpha$

Pengurangan $\alpha=0.1 * \alpha$

Kelas-kelas yang didapatkan sebagai hasil dari lapisan kompetitif ini hanya tergantung pada jarak antara vektor-vektor input. Jika dua vektor input mendekati sama, maka lapisan kompetitif akan meletakkan kedua vektor input tersebut ke dalam kelas yang sama. Gambar 1 menunjukkan jaringan LVQ dengan enam unit pada lapisan input dan dua unit (neuron) pada lapisan output.

IJCCS Vol. 7, No. 2, July 2013 : 145 - 154 


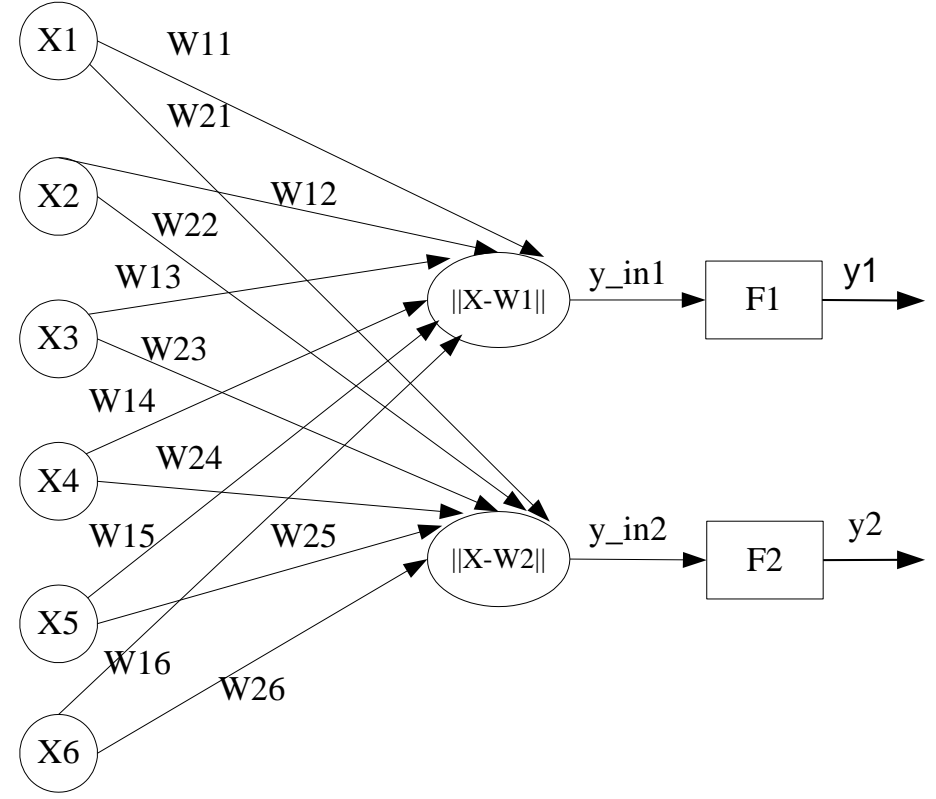

Gambar 1 Contoh arsitektur jaringan LVQ.

\section{4. $C 4.5$}

Sebuah pohon keputusan adalah sebuah struktur yang dapat digunakan untuk membagi kumpulan data yang besar menjadi himpunan-himpunan record yang lebih kecil dengan menerapkan serangkaian aturan keputusan [9].

Secara umum algoritma C4.5 untuk membangun pohon keputusan adalah sebagai berikut [10] :

1. Pilih atribut sebagai root

2. Buat cabang untuk masing-masing nilai

3. Bagi kasus dalam cabang

4. Ulangi proses untuk masing-masing cabang sampai semua kasus pada cabang memiliki kelas yang sama.

Untuk memilih atribut sebagai akar, didasarkan pada nilai gain tertinggi dari atributatribut yang ada. Untuk menghitung gain digunakan persamaan (7) [11]:

$$
\operatorname{Gain}(S, A)=\operatorname{Entropy}(S)-\sum_{i=1}^{n} \frac{\left|S_{i}\right|}{|S|} * \operatorname{Entropy}\left(S_{i}\right)
$$

Dengan :

$\left\{\mathrm{S}_{1}, \mathrm{~S}_{2}, \mathrm{~S}_{3}, \ldots ., \mathrm{S}_{\mathrm{n}}\right\}=$ partisi $\mathrm{S}$, sesuai dengan nilai atribut $\mathrm{A}$

A : Atribut

$\mathrm{n} \quad$ : Jumlah partisi atribut A

$\left|S_{\mathrm{i}}\right|$ : Jumlah kasus pada partisi $\mathrm{S}_{\mathrm{i}}$

$|\mathrm{S}|$ : Jumlah kasus dalam $\mathrm{S}$

Sedangkan perhitungan nilai entropy menggunakan persamaan (8) [11]:

Dengan :

$$
\operatorname{Entropy}(S)=\sum_{i=1}^{n}-p i * \log _{2} p i
$$

S : Himpunan kasus

$\mathrm{n} \quad$ : Jumlah kasus pada partisi $\mathrm{S}$

pi : Proporsi $S_{\mathrm{i}}$ terhadap $\mathrm{S}$ 


\section{HASIL DAN PEMBAHASAN}

\subsection{Analisis Kebutuhan}

Untuk menjalankan sistem klasifikasi mahasiswa ini, dibutuhkan beberapa hal baik kebutuhan fungsional maupun kebutuhan proses. Untuk kebutuhan fungsional sebagai berikut :

1. Fasilitas memasukkan data

2. Fasilitas melihat data

3. Fasilitas menambah data

4. Fasilitas memilih attribut yang digunakan

5. Fasilitas membagi data

6. Fasilitas mengubah parameter pembelajaran

7. Fasilitas pengujian

8. Fasilitas perhitungan akurasi

9. Fasilitas melihat hasil pembagian data

Sedangkan kebutuhan proses, sebagai berikut :

1. Proses encoding

2. Proses perhitungan kemiripan

3. Proses pembentukan jaringan syaraf tiruan

4. Proses pembentukan tree

\subsection{Data}

Data mahasiswa yang telah didapatkan dari sistem informasi akademik program diploma sekolah vokasi UGM akan disimpan dalam format file arff. Data mahasiswa yang dimaksud adalah :

1. Usia

2. Jumlah saudara

3. Jumlah tanggungan

4. Jurusan di SMTA

5. Pendidikan ayah

6. Pendidikan ibu

7. Penghasilan orang tua

8. Nilai

\subsection{Diagram Use Case}

Pada sistem ini hanya terdapat satu pengguna saja. pengguna merupakan satu-satunya actor yang berperan dalam sistem. Pengguna berinteraksi dengan sistem dalam bentuk pilih data, lihat data, tambah data, membentuk jst, set parameter belajar, membentuk pohon, menjalankan Nearest Neighbour, bagi data, uji akurasi, lihat data belajar, lihat data test dan melakukan test. Gambaran spesifikasinya ditunjukkan pada Gambar 2. 


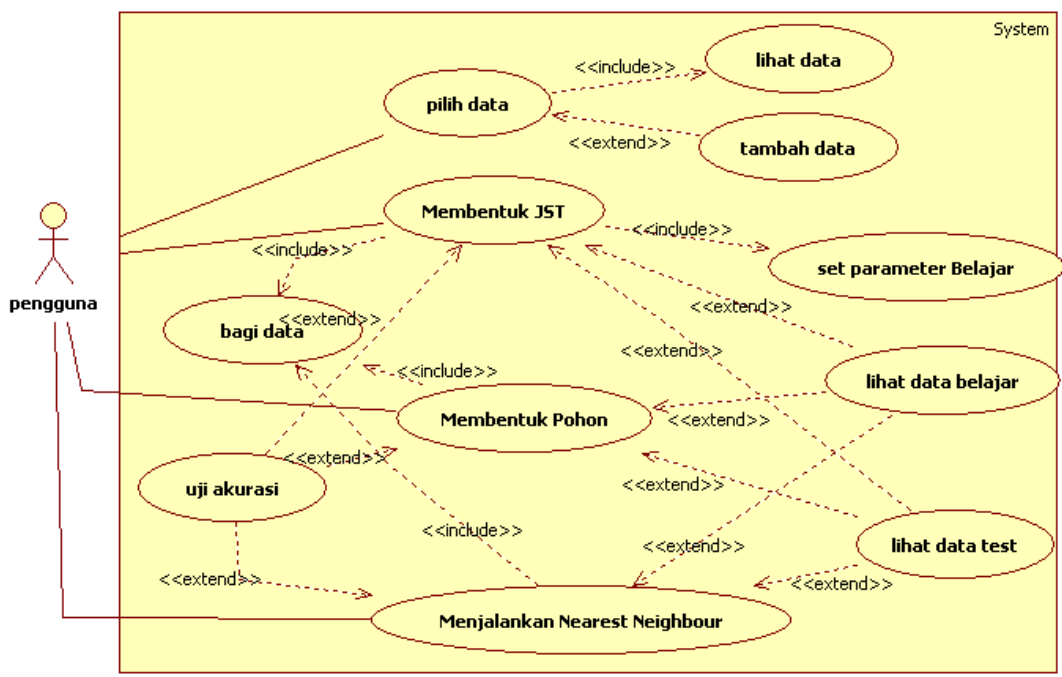

Gambar 2 Diagram Use Case

\subsection{Diagram Kelas}

Pada penelitian ini terdapat lima paket yang tersusun dari beberapa kelas. Kelima paket tersebut adalah paket C45, jstLVQ, NearestNeighbour, tesisPerbandingan dan utility. Tiga paket pertama (C45, jstLVQ, NearestNeighbour) merupakan representasi dari tiga algoritma yang diperbandingkan sedang dua paket berikutnya merupakan paket bantuan untuk sistem. Diagram kelas ditunjukkan pada Gambar 3.

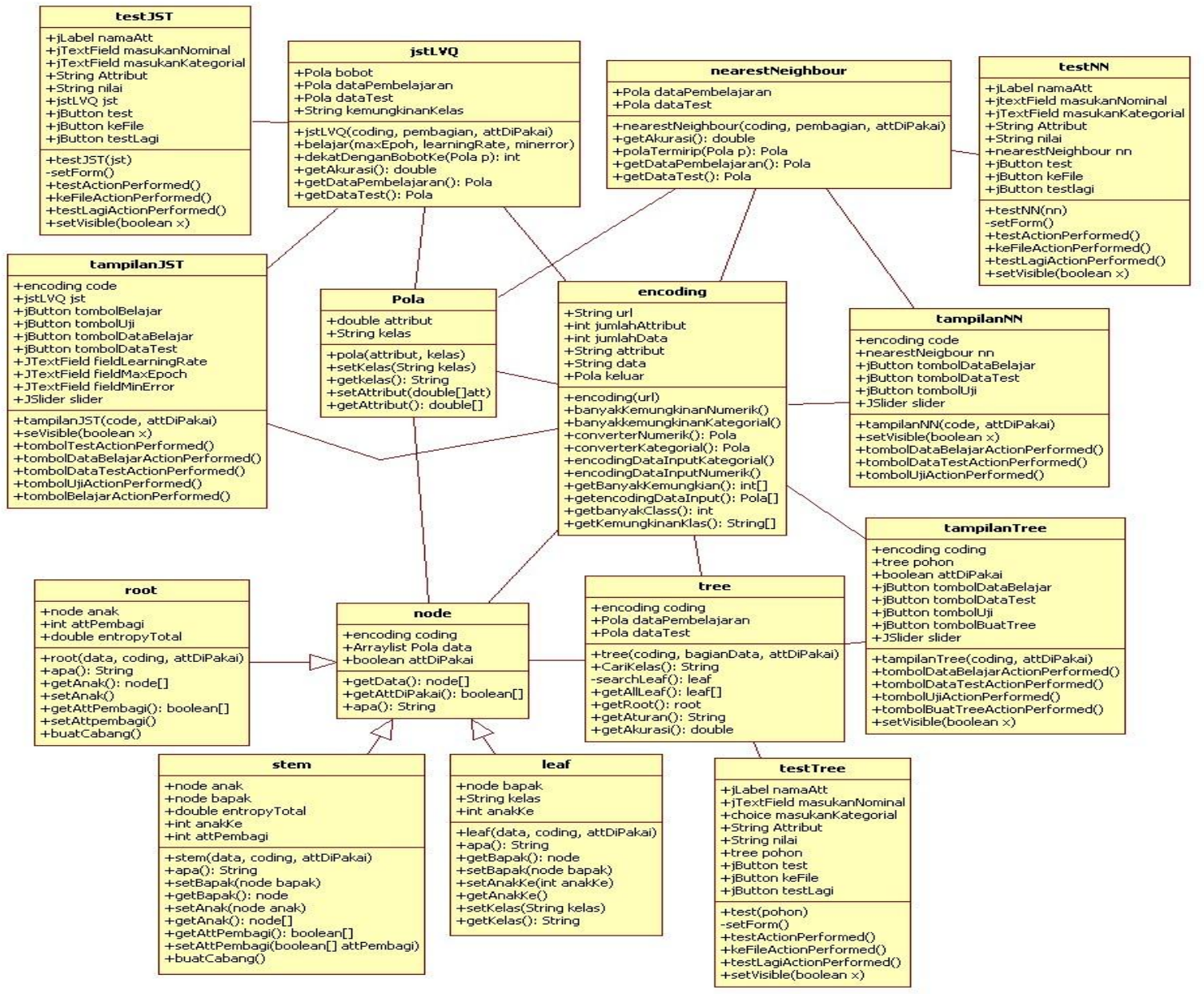

Gambar 3 Diagram kelas 


\subsection{Pengujian dan Pembahasan}

Untuk mengetahui perbandingan ketiga algoritma, akan dilakukan enam macam pengujian menggunakan beberapa dua buah file arff yang menyimpan data mahasiswa yang telah dibentuk. Pengujian tersebut akan dilakukan dalam 2 bentuk. Bentuk pertama adalah pembagian data mahasiswa 2009 sebagai data pembelajaran dan data mahasiswa 2010 dan 2011 sebagai data test. Bentuk kedua adalah pembagian data mahasiswa 2009 dan 2010 sebagai data pembelajaran dan data mahasiswa 2011 sebagai data test.

Sebelum melakukan pengujian perbandingan, dilakukan pengujian parameter untuk algoritma lvq dalam pembentukan jaringan syaraf tiruan untuk mendapatkan konfigurasi parameter terbaik yang nantinya digunakan dalam pengujian perbandingan.

\section{Pengujian tahap 1}

Pengujian perbandingan algoritma ini menggunakan data mahasiswa angkatan 2009 sebagai data pembelajaran, sedangkan data mahasiswa angkatan 2010 dan 2011 digunakan sebagai data test. Dari keseluruhan data mahasiswa, yaitu sebanyak 295 data mahasiswa, jumlah data mahasiswa angkatan 2009 terdapat sebanyak 76 mahasiswa. Dengan demikian, pembagian data menggunakan $27 \%$. Untuk parameter pembelajaran jaringan syaraf tiruan, digunakan hasil pengujian parameter yang telah didapatkan. Hasil dari pengujian ini ditunjukkan pada Tabel 1.

Tabel 1 perbandingan tahap 1

\begin{tabular}{|c|c|c|c|c|}
\hline \multirow{2}{*}{ Algoritma } & \multicolumn{2}{|c|}{ mhsMate.arff } & \multicolumn{2}{c|}{ mhsProtek1.arff } \\
\cline { 2 - 5 } & $\begin{array}{c}\text { waktu perhitungan } \\
\text { akurasi (ms) }\end{array}$ & akurasi (\%) & $\begin{array}{c}\text { waktu perhitungan } \\
\text { akurasi (ms) }\end{array}$ & akurasi(\%) \\
\hline $\begin{array}{c}\text { Nearest } \\
\text { Neighbour }\end{array}$ & 47 & 31,96 & 31 & 39,44 \\
\hline c45 & 0 & 37,58 & 0 & 40,00 \\
\hline jst-lvq & 0 & 27,35 & 0 & 35,77 \\
\hline
\end{tabular}

Dari Tabel 1, dapat diambil kesimpulan bahwa untuk pengujian dengan pembagian data $27 \%$, algoritma c45 menghasilkan akurasi tertinggi untuk kedua mata kuliah, walau memerlukan waktu pengujian yang relatif kecil, yaitu mendekati $0 \mathrm{~ms}$. Sedangkan algoritma nearest neighbour menempati peringkat kedua untuk semua mata kuliah. Untuk mata kuliah matematika, algoritma ini memerlukan waktu lebih lama, yaitu $47 \mathrm{~ms}$ dan menghasilkan akurasi 31,96, sedangkan untuk mata kuliah pemrograman terstruktur 1 (protek1), algoritma ini menghasilkan akurasi 39,44. Akurasi terendah dihasilkan oleh algoritma jst-lvq yang hanya menghasilkan tingkat akurasi 27,39 dan 35,77.

\section{Pengujian tahap 2}

Pengujian perbandingan algoritma ini menggunakan data mahasiswa angkatan 2009 dan 2010 sebagai data pembelajaran, sedangkan data mahasiswa angkatan 2011 digunakan sebagai data test. Dari keseluruhan data mahasiswa, yaitu sebanyak 295 data mahasiswa, jumlah data mahasiswa angkatan 2009 dan 2010 terdapat sebanyak 204 mahasiswa. Dengan demikian, pembagian data menggunakan $70 \%$. Untuk parameter pembelajaran jaringan syaraf tiruan, digunakan hasil pengujian parameter yang telah didapatkan. Hasil dari pengujian tersebut ditunjukkan pada Tabel 2.

Tabel 2 perbandingan tahap 2

\begin{tabular}{|c|c|c|c|c|}
\hline \multirow{2}{*}{ Algoritma } & \multicolumn{2}{|c|}{ mhsMate.arff } & \multicolumn{2}{c|}{ mhsProtek1.arff } \\
\cline { 2 - 5 } & $\begin{array}{c}\text { waktu perhitungan } \\
\text { akurasi (ms) }\end{array}$ & akurasi (\%) & $\begin{array}{c}\text { waktu perhitungan } \\
\text { akurasi (ms) }\end{array}$ & akurasi(\%) \\
\hline $\begin{array}{c}\text { Nearest } \\
\text { Neighbour }\end{array}$ & 31 & 76,92 & 47 & 80,89 \\
\hline c45 & 0 & 60,60 & 0 & 56,66 \\
\hline jst-lvq & 0 & 37,67 & 0 & 65,16 \\
\hline
\end{tabular}


Dari Tabel 6.9, dapat kita ambil kesimpulan bahwa, untuk pengujian dengan pembagian data $70 \%$, algoritma nearest neighbour menghasilkan akurasi tertinggi untuk kedua mata kuliah, walau memerlukan waktu pengujian yang relatif lebih lama. Akurasi terendah untuk mata kuliah matematika adalah jst-lvq yang menghasilkan akurasi 37,67. Walau demikian, ternyata algoritma jst-lvq menghasilkan akurasi lebih tinggi daripada algoritma c45 untuk mata kuliah pemrograman terstruktur 1, yaitu 65,16 berbanding 56,66 walau waktu ujian yang diperlukan sama-sama mendekati $0 \mathrm{~ms}$.

\section{KESIMPULAN}

Berdasar data-data yang diperoleh sebagai hasil pengujian dari implementasi perbandingan algoritma, dapat disimpulkan bahwa :

1. Telah berhasil dibangun sebuah sistem dengan tiga sub sistem yang mengimplementasikan algoritma nearest neighbour, $C 45$ dan $L V Q$.

2. Sistem yang telah dibangun mampu membandingkan ketiga algoritma dengan baik berdasar masukan data mahasiswa yang telah tersimpan dalam file bertipe arff.

3. Penentuan kemampuan mahasiswa lebih tepat bila menggunakan algoritma nearest neighbour bila dibandingkan dengan algoritma lvq dan c45. Akan tetapi untuk jumlah data pembelajaran yang relatif sedikit, lebih tepat menggunakan algoritma c45.

4. Algoritma nearest neighbour memerlukan waktu yang lebih lama untuk mendapatkan klasifikasi kemampuan mahasiswa bila dibandingkan dengan algoritma $L V Q$ dan $C 45$.

\section{SARAN}

Saran yang diberikan untuk pengembangan sistem perbandingan selanjutnya adalah:

1. Sistem hendaknya memberikan lebih banyak pilihan implementasi algoritma.

2. Sistem hendaknya memiliki tampilan yang lebih menarik.

\section{UCAPAN TERIMA KASIH}

1. Ayah dan Ibu tercinta "Mangun Budiyanto dan Milyatun", juga saudara-saudaraku tercinta "Muh. Zaki Riyanto, Muh. Fakhrurreza dan Muh Rashif Hilmi" yang selalu mendukung dan memberi semangat dan doa kepada penulis.

2. Risti Wijayanti yang telah setia menemani dan selalu mengobarkan semangat kepada penulis.

3. Teman-teman Dosen dan Staff D3 Mipa Vokasi, Dika, Anin, Firma, Tesar, Mas Isnan, Tyas, Pak Nasir, Pak Sigit, pak Nur, Pak Panggih, Tri, Mas Bari, Anang, Mbak eny, Mbak Ari, Ony yang selalu penuh intrik dan asumsi sehingga mewarnai kehidupan penulis.

4. Teman - teman yang banyak membantu dalam proses pembuatan tulisan ini, khusunya Pak Anifuddin Aziz. 


\section{DAFTAR PUSTAKA}

[1] Yang, B.S., Han, T., Kim, Y.S., 2004, Integration of ART-Kohonen and casebased reasoning for intelligent fault diagnosis, Expert Systems with Applications $16,387-395$.

[2] Pall, Sankar K., Shiu, Simon C.K., 2004, Foundation of Soft Case Based Reasoning, John Wiley and Sons, USA

[3] Jha, G., Hui, S.C., Foo, S., 1999, A hybrid case-based reasoning and neural network approach to online intelligent fault diagnosis, Proceedings of 3rd International ICSC Symposia on Intelligent Industrial Automation and Soft Computing Genoa, Italy, 376-381

[4] Riesbeck, C. dan Schank, R., 1989, Inside Case-based Reasoning, Hillsdale, NJ : Lawrence Erlbaum.

[5] Watson, I., 1997, Applying Case-base Reasoning:Techniques for Enterprise Systems, Morgan kaufmann Publishers Inc, San Francisco, CA.

[6] Aamodt, A., dan Plaza, E., 1994, Case-based reasoning: foundational issues, methodological variations, and system approach, AI Communications. vol. 7, no. 1, pp. 39-59.

[7] Wilson, D. R. dan Martinez, T. R., 1997, Improved Heterogeneous Distance Functions, AI Access Foundation and Morgan Kaufmann Publishers. Provo, Utah USA.

[8] Kusumadewi S, 2003, Artificial Intelligence (Teknik dan Aplikasinya), Graha Ilmu, Yogyakarta

[9] Berry, Michael J.A., Linoff, Gordon S., Data Mining Techniques For Marketing, Sales, and Customer RelationshipManagementSecond Edition, Wiley Publishing, Inc., Indianapolis, Indiana (2004)

[10] Larose, Daniel, T., 2005, Discovering Knowledge in Data: an Introduction to Data Mining, John Wiley and Sons, USA

[11] Craw, S.,2005, Case Based Reasoning : Lecture 3: CBR Case-Base Indexing,www.comp.rgu.ac.uk/staff/smc/teaching/cm3016/Lecture-3-cbrindexing.ppt 